\section{Arianne Struik}

Gz-psycholoog Arianne Struik is directeur van het Institute for Chronically Traumatized Children (ICTC) in Scarborough (Perth, West- Australië) dat gespecialiseerd is in de behandeling van getraumatiseerde kinderen en hun families. Ze is auteur van het boek Slapende Honden? Wakker maken! Als 'flying psych' behandelt ze getraumatiseerde kinderen en volwassen in afgelegen gebieden.

\title{
Down Under: Living on the edge
}

Australië wordt in de media vaak afgespiegeld als een gevaarlijk land. Toen hij vorig jaar op bezoek kwam, durfde mijn achtjarige neefje nauwelijks het vliegtuig uit, uit angst dat de krokodillen en haaien hem zouden opvreten. Hij was ervan overtuigd dat mijn partner altijd een hamer bij zich had, om spinnen dood te slaan. $\mathrm{Nu}$ valt dat natuurlijk reuze mee, maar de mensen staan hier wel dichter bij de dood voor mijn gevoel.

Sjef, mijn eerste cliënt van vandaag, vertelt over een ongeluk dat hem nog steeds dwarszit. Hij werkte in een fabriek waar gelatine wordt gemaakt door koeienhuiden chemisch te bewerken met verschillende substanties. Op een ochtend bleken de koeienhuiden per ongeluk de hele nacht, in plaats van een uurtje, in de chemische stof te hebben gelegen en de huiden waren helemaal opgelost. Zijn baas, die dat ook nog nooit had meegemaakt, gaf het team de opdracht om de substantie in een plastic container weg te pompen. Maar na een paar minuten bleken er giftige dampen vrijgekomen en viel zijn collega Kip neer. Sjef redde Kip met gevaar voor eigen leven, maar in plaats van als held te worden bedankt, probeerde zijn baas hem te ontslaan.

Harry, een volgende cliënt, was getuige van een gasexplosie waarbij zijn baas om het leven kwam. Het afvalverwerkingsbedrijf nam het niet zo nauw met de veiligheid en voor zijn baas, die de onveiligheid al vele malen had aangekaart, dreigde ontslag. Harry worstelde enorm met de beelden van zijn uiteengerukte lichaam, en met een schuldgevoel omdat hij niet voor hem was opgekomen toen zijn baas het werk weigerde.

Dan komt cliënt Chris, een kraanmachinist bij een van de fabrieken in het dorp waar ik woon. Hij kreeg paniekaanvallen op het werk, nadat hij een aantal incidenten had meegemaakt die bijna verkeerd afliepen. Bij het laatste ongeluk was er een enorm krat losgeraakt, wat op een haar

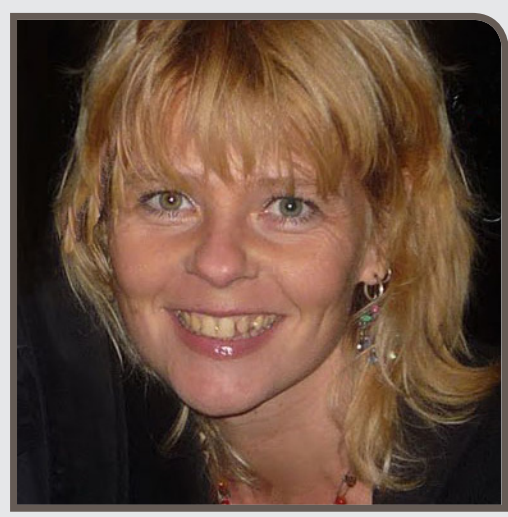

na zijn collega had gemist. Dat was de druppel geweest. De afgelopen jaren had de fabriek flink bezuinigd, omdat er door de recessie minder vraag was naar de grondstoffen die Australië produceert, zoals staal en kolen. Het materiaal in de fabriek was ondeugdelijk en er was te weinig personeel. Als Chris me vraagt of ik hem van zijn angst kan afhelpen, overvalt mij een moedeloosheid. Ja, de werkeloosheid is zo hoog dat hij het zich niet kan permitteren om ontslag te nemen, maar doorwerken zou z'n dood kunnen worden.

Dan krijg ik een sms van mijn partner, die weliswaar in een chemische fabriek werkt, maar gelukkig een kantoorbaan heeft. 'Ik moest de jongens even helpen om dit op te ruimen', schrijft hij onder een foto waarop hij een bezem vasthoudt met daarop een agressieve drie meter lange King Brown, een van de meest giftige slangen in Australië. 